\title{
BIOECONOMY AND SOCIAL RESPONSIBILITY IN THE SUSTAINABLE HOTEL INDUSTRY
}

\author{
Claudia Gabriela Baicu ${ }^{1}$, Iulia Monica Oehler-Sincai ${ }^{2}$, Olimpia State ${ }^{3}$ \\ and Delia Popescu ${ }^{4 *}$ \\ 1) Spiru Haret University, Bucharest, Romania. \\ ${ }^{2)}$ Institute for World Economy, Romanian Academy, Bucharest, Romania. \\ 3) 4) Bucharest University of Economic Studies, Romania.
}

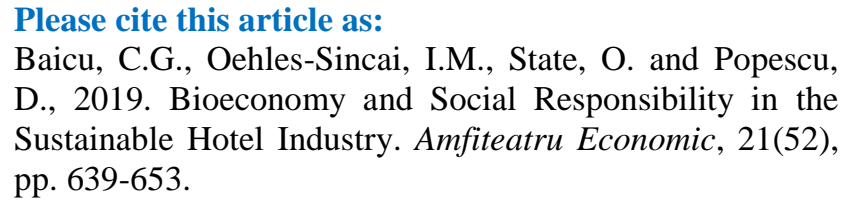

Baicu, C.G., Oehles-Sincai, I.M., State, O. and Popescu, D., 2019. Bioeconomy and Social Responsibility in the Sustainable Hotel Industry. Amfiteatru Economic, 21(52), pp. 639-653.

DOI: $10.24818 / \mathrm{EA} / 2019 / 52 / 639$

\section{Article History}

Received: 30 March 2019

Revised: 13 June 2019

Accepted: 15 July 2019

\begin{abstract}
The aim of this article is to investigate strategies and practices of bioeconomy implemented by hotels in Romania in the context of increasing area and scale of corporate social responsibility initiatives worldwide. After presenting the conceptual framework necessary for the present investigation and selecting the most relevant papers from the literature, the research focuses on Romania's experience through: statistical analyzes, the investigation of hotel websites regarding social responsibility and bioeconomy practices and a semiquantitative study having as a research tool the individual semi-structured interview with hotels representatives. The Romanian market underscores relevant contrasts between four and five star hotels and the others categories. Hotels in the first category, often belonging to international chains, benefit from the strategies of sustainable development and social responsibility within the group, in contrast with other hotels. The investigation concludes that, as long as social responsibility continues to have a voluntary character, there will be a limited number of best practices as regards developing bioeconomy in the Romanian hotel industry. Consequently, we propose the introduction of legislative measures to stimulate all companies, regardless of size, to report non-financial information, as well as raising awareness and education in the direction of promoting the bioeconomy.
\end{abstract}

Keywords: social responsibility, bioeconomy, sustainable hotel industry, sustainable business.

JEL Classification: M14, Q01, Q57, Z32

* Corresponding author, Delia Popescu - delia.popescu@ com.ase.ro 


\section{Introduction}

Three interrelated factors have highlighted the need to address corporate social responsibility (CSR) in the Romanian hospitality industry through bioeconomy. First of all, for more than 40 years already, there have been concerns about the negative effects of mass tourism on the environment (Cohen, 1978). These concerns have intensified in the recent period, in the context of climate change and growing pressures on the environment. Second, in the context of the European Union's new strategy on bioeconomy (European Commission, 2018a) "a sustainable bioeconomy must value natural resources, diminish environmental pressures, and increase the use of sustainable renewable products, restore and enhance ecosystems' functions and biodiversity. It will promote more sustainable, circular and post-waste food systems and primary production on land and sea". Nevertheless Romania is the country with the lowest bioeconomic productivity in the EU, despite its considerable potential (ICECHIM, 2016). Third, according to Eurostat data (2019), about $65 \%$ of tourists' overnight stays in the European Union are in hotel accommodation units, indicating the overwhelming importance of this tourism component for the industry as a whole.

Therefore, the hospitality industry is called upon to play a major role in bioeconomy by promoting sustainable practices such as: energy conservation, environment protection, waste reduction, recycling programs, increased use of natural cleaning products and natural food from local cuisine. Moreover, the fulfillment of bioeconomy and sustainability criteria becomes more and more important against the background of increasing number of tourists or the significant amount of energy consumed. National and multinational companies, including hotels, have been determined to rethink their business models and adopt sustainable and rational use of resources, diminishing of waste resulting from production processes, preservation of environment and nature, consumers' education towards responsible consumption (Andronie et al., 2019, p. 258).

Starting from these premises, the key question around which this analysis is structured is as follows: "Which are the limits of CSR in the Romanian hotel industry considering the necessity of developing the bioeconomy?" The paper explores strategies and practices of bioeconomy implemented by hotels in Romania, against the growing awareness of sustainable development and social responsible practices.

In order to solve the problem to be investigated, the paper is structured around the following main sections: (1) literature review; (2) research methodology; (3) results and discussions. The literature review follows the deep links between (i) CSR, (ii) bioeconomy and sustainable development, and (iii) hotel industry, being organized on these three dimensions. The analyzed references allow us to conclude that the hotel industry plays an important role in the implementation and promotion of policies in the field of bioeconomy and sustainable development, and CSR can be an effective tool for achieving these objectives. This investigation brings a new contribution as regards the situation in Romania, so far there are no studies specifically addressing this issue. The Methodology section outlines the methods used to investigate the issue, and the final part includes the results of the research, as regards: (i) the interpretation of the objectives included in codes of conduct, initiatives and reports on the sustainability of hotels of prime importance; (ii) analysis of the hotel market in Romania; (iii) the stage of applying the criteria of sustainable development in hotels in Romania. The conclusions, which synthesize the theoretical and managerial implications, as well as the limits and perspectives of the research carried out, conclude the paper. 


\section{Literature review}

\subsection{CSR - conceptual framework}

Along with the evolution of the concept of sustainable development, following the adoption of the Brundtland Report in 1987, and the intensification of efforts to define clear objectives of the international community under the aegis of the United Nations (UN, 2000; $\mathrm{UN}, 2015$ ), the scope of the concept of corporate social responsibility was broadened.

Carroll (2008), starting with Murphy (1978), divides the history of CSR into several stages, its origins being found in filthy philanthropic actions of companies at the end of the 19th century. Since the 1950s, the emphasis has been on awareness and recognition of the need of companies' responsibility for society (1953-1967), then to specific sectorial actions, such as combating pollution and racial discrimination (1968-1973) and the integration of these actions in the current activities of companies (1974-1978). In recent decades, social responsibility has become a strategic marketing tool, being one of the major determinants of company prestige and reputation (Sindhi, Padhi and Maurya, 2018). Company reputation is not only a decision-making criterion for consumers and the workforce, but also for business partners. In the decision-making process, more than half of the institutional investors take into account not only financial criteria, but also aspects of corporate governance, business ethics, environmental risks, relations with civil society and cultural diversity (KPMG, 2018).

Social responsibility codes, adopted by either international organizations (such as those under the UN framework) or by some companies (generally multinationals), have a special role to play in "guiding" business, society and partners towards compliance with rules and norms of conduct. For instance, the "Global Code of Ethics in Tourism", adopted in 1999, concentrates in ten articles a series of general principles regarding tourism sustainability, cultural heritage preservation and social welfare. Company codes are instead more precise, some are more ambitious, others more brief, pointing priorities according to their financial capacity.

Another example is the International Standardization Organization (ISO). For instance, ISO 26000 provides a valuable guidance on social responsibility issues at international level. Companies' competitiveness and reputation, workers' retention and productivity, relationship with customers, community or government are among the things the performance on social responsibility of an organization can influence (ISO, 2010).

At the European level, the importance of non-financial information disclosure by large companies was recognized through the Directive 2014/95/EU. According to this directive, the companies with more than 500 employees have to regularly report information related to social and environmental matters.

The concept of social responsibility was introduced in Romania in the 1990s, when several non-government organizations (NGOs) were founded, but the major involvement in CSR activities started only after 2000. Multinational companies engaged in CSR activities had the most important role in CSR promoting by the private sector (Mandl and Dorr, 2007). In 2011, an analysis of the CSR in Romania was realized by Obrad, Petcu, Gherheş and Suciu (2011). The authors mentioned increased importance of both CSR initiatives in Romania and budgets allocated to these activities. 


\subsection{Bioeconomy and sustainable development}

Bioeconomy "is at the center of sustainable economic strategies of countries worldwide" (Anand, 2016). The United Nations document - "Transforming our world: the 2030 Agenda for Sustainable Development" - is "a plan of action for people, planet and prosperity" (United Nations, 2015, p. 1), comprising 17 Sustainable Developments Goals.

The specialty literature and practice in the field underline the important role the bioeconomy plays in accomplishment of the UN Sustainable Development Goals. To this end, the European Bioeconomy Alliance (EBA, 2018) provides concrete examples of how the EU bioeconomy supports these Sustainable Developments Goals. Among the goals related to bioeconomy are mentioned: (1) the second goal, on food security and sustainable agriculture; (2) the seventh goal, concerning sustainable energy; (3) the eighth goal, promoting sustainable economic growth and decent work; (4) the goal number nine, regarding sustainable industrialization and innovation; (5) the twelfth goal, referring to sustainable consumption and production; (6) the thirteenth objective, with respect to combat climate change. Similarly, there are other organizations that provide valuable examples on how the Bio-Based Industries contribute to the UN Sustainable Development Goals achievement (see, for example, Biobased Industries Consortium, 2018).

The United Nations Global Compact established ten principles responsible businesses have to incorporate in their activities, including: protection of human rights, abolition of child labor, elimination of discriminatory practices regarding employment, environment protection, anti-corruption behavior. Apart from the positive impact on planet and people, by meeting these principles, companies are also positively impacted on the success on longterm (UNGC, 2014).

A crucial role in sustainability reporting worldwide plays the Global Reporting Initiative (GRI) that established the first global standards for sustainability reporting. These standards are a reference framework for organizations all around the globe (GRI, 2013).

The global efforts concerning sustainability are also strengthen by the Accountability Framework Initiative that delivered core principles on companies' commitments in responsible supply chains (Accountability Framework, 2018).

\subsection{Bioeconomy, tourism and sustainable hotel industry}

The main bridge between the hospitality industry and the bioeconomy is the demand for goods and services produced in key-sectors of the bioeconomy, which once again demonstrates the role of the responsibility of the hotel industry companies for sustainable development. Community initiatives are a general framework conducive to good interaction between the hospitality industry and the bioeconomy, but, as long as they are not binding, their potential will not be achieved in practice.

Currently, sustainable tourism and hotels are a topic of interest worldwide; therefore, in the literature, there are a lot of studies focusing on various countries or regions. For instance, the role the tourism plays in the bioeconomy of Poland was mentioned by PrzezbórskaSkobiej (2017). The analyses were performed from a regional perspective. In this context, the paper reveals that bioeconomy was indicated as smart-specialization in two Poland regions, the development of tourism being often associated with development of medical tourism. 
By referring to the hotel industry in Taiwan, the study of Mak and Chang (2019) underlines some environmental strategies that should be taken into consideration, among which adoption by the government of appropriate legislation in the field and increased awareness of hotels management and owners on environment matters.

Issues related to sustainable tourism development are also presented by Jashi (2018), this time with reference to the tourism sector in Georgia. The study findings underline the importance of environmental education as a driving force for promoting friendly environmental behavior of tourists and development of sustainable tourism. To this end, besides the environmental policies adopted by state, business and civil society are also called to contribute by taking actions.

Abaeian, Yeoh and Khong (2014) explore the CSR initiatives of Malaysian hotels, emphasizing the managers' motivations to involve in CSR activities. The quality of service in spa hotels in Serbia was examined by Blešić, Čerović and Dragićević (2011). In the authors' opinion, the implementation of social responsibility principles is a major factor to get service quality.

Romania has its own national strategy for sustainable development 2030 and also a Master Plan for the Development of National Tourism (2007-2026), in collaboration with the World Tourism Organization (Government of Romania, 2018). The Master Plan is supported by sectorial strategies, such as those on: ecotourism, strategic and operational marketing, spa tourism (OECD, 2018). However, it does not have a specific strategy for the hotel industry from the perspective of bioeconomy.

Literature in the field is not extensive either. Certain research has been carried out on CSR in the hospitality industry in Romania, but analyzes have not specifically targeted the CSR contribution to the implementation of practices and strategies specific to bioeconomy in hotels in Romania. Grigoras and Albu (2015) explore the CSR actions performed by four hotels located in Brasov, one of the most beautiful Romania cities. The results reveal that the hotels are involved to a small extend in such actions. Similarly, by referring to the CSR practices of the top Romanian travel agencies, Moisescu (2014) notices the low engagement in CSR activities of these agencies. The research is based on the analysis of these agencies websites. It is worth noting that the website of only one agency include references on environment CSR issues. The paper of Ionescu et al. (2018) focuses on investigating the effects of implementing integrated management systems and the CSR initiatives impact on the market value of Romanian hotel industry companies. Their findings reveal a direct correlation between implementation of integrated management system and the companies' economic performance. Concerning CSR influence, the study also demonstrates a positive correlation between the existence of CSR initiatives and the increase of companies' market value for the Romanian hospitality industry.

\section{Methodology}

In order to investigate strategies and practices of bioeconomy implemented by hotels in Romania, in the first stage of the research, the literature in the field was analyzed. Papers indexed in international databases, especially Web of science, were explored. Another criterion used in identifying and choosing the papers was the geographical diversity of the case studies concerning tourism. 
A special attention was devoted to the United Nations Sustainable Development Goals and the way bioeconomy contributes to their achievement, as reflected in documents issued by reference organizations in the field. Due to the importance of the European and international guidelines in disclosure of non-financial information concerning the social and environmental business impact, relevant documents issued by well-recognized organization such as the International Organization for Standardization were also reviewed. At the European level, the Directive 2014/95/EU regarding disclosure of non-financial information by large companies was mentioned. At the same time, the contribution of the Global Sustainable Tourism Council (GSTC) in building an important framework for sustainable tourism was considered.

In addition to the literature, social responsibility codes, detailed initiatives and hotel reports on their contribution to sustainable development are useful tools for benchmarking the sustainability approach. One of the databases belonged to the international independent organization the Global Reporting Initiative, which, since 1997, has been collecting and publishing companies' sustainability reports on a dedicated platform (GRI, 2019).

The second stage includes a statistical analysis of the hotels present in Romania and a research regarding the way CSR reports/statements of hotels in Romania reveal bioeconomy practices. The case study on Romania has been realized by analyzing the database of the National Institute of Statistics and web-sites of hotels during FebruaryMarch 2019. Several site-visits to some hotel receptions in Bucharest in order to get more information concerning their CSR practices have been also performed during this stage. In addition, we have resorted to the Ministry of Tourism's database regarding the 1-3-star hotels. For each of these hotels, we have accessed their own websites and, in their absence, the specific links on the websites of the tour operators. On the basis of the information obtained, the relevant measures adopted by them regarding the bioeconomy were synthesized.

In the third stage, eighteen interviews concerning the implementation of sustainable criteria in hotels in Romania have completed our research. Individual, semi-structured interviews were conducted to stimulate respondents to make also a narrative analysis. The research is semi-quantitative, allowing authors to centralize and interpret relevant aspects resulting from respondents' answers.

\section{Results and discussions}

\subsection{Interpretation of primordial goals included in codes, initiatives, and reports regarding sustainable hotel industry}

In practice, a number of criteria have been highlighted in order to estimate the efficiency of some branches of the economy in terms of social responsibility. Table no. 1 summarizes some of them. The environment, which is strongly linked to bioeconomy, and society are among the most important. The factors related to bioeconomy include: greenhouse gas emissions, energy security and renewable energy, water management, waste management, maximizing social and economic benefits for the local community, increasing the value of cultural heritage, reducing the negative impact on the environment. 
Table no. 1: Key factors in estimating the efficiency as regards social responsibility, adapted for the hotel industry

\begin{tabular}{|l|l|}
\hline \multicolumn{1}{|c|}{ Studies } & \multicolumn{1}{c|}{ Factors/criteria } \\
\hline Ricaurte (2018) & $\begin{array}{l}\text { Emissions of greenhouse gases (per night, per year, relative to } \\
\text { the number of occupied rooms, relative to the surface, etc.); The } \\
\text { amount of water used (per night, per year, relative to the number } \\
\text { of occupied rooms, etc.); The share of renewable energy in the } \\
\text { total energy consumption of the hotel }\end{array}$ \\
\hline $\begin{array}{l}\text { Global Sustainable } \\
\text { Tourism Council }\end{array}$ & $\begin{array}{l}\text { The criteria are organized in four sections that refer to: } \\
\text { (1) sustainable management; (2) benefits and negative impact to } \\
\text { the local community; (3) benefits and negative impact to cultural } \\
\text { heritage; (4) benefits and negative impact to the environment. }\end{array}$ \\
\hline $\begin{array}{l}\text { Global Reporting } \\
\text { Initiative (GRI, 2013) }\end{array}$ & $\begin{array}{l}\text { Economic factors (impact on local communities), social } \\
\text { (working conditions, migration, local communities, } \\
\text { discrimination), environmental (standards for the exploitation } \\
\text { and use of raw materials, the management and use of plastic } \\
\text { products, energy consumption, energy efficiency, fuel } \\
\text { consumption, water consumption, biodiversity, waste } \\
\text { management, etc.), others (corporate governance, food security, } \\
\text { cultural heritage). }\end{array}$ \\
\hline $\begin{array}{l}\text { Băleanu, Chelcea and } \\
\text { Stancu (2011) }\end{array}$ & $\begin{array}{l}\text { Actions related to community, environment, education, health, } \\
\text { sports, culture, workforce, organization of activities. }\end{array}$ \\
\hline
\end{tabular}

The most active hotels in the area of social responsibility are those with the most consistent financial resources. In the list of the largest companies worldwide according to four criteria (sales, profit, assets and market value) are included 12 hotels (Forbes, 2018), of which four are also present on the Romanian market: Marriott (USA), Hilton (USA), Accor (France) and InterContinental Hotels (United Kingdom). Table no. 2 summarizes individual initiatives of the four hotels in the CSR field, including specific bioeconomy measures.

Table no. 2: Relevant hotels' initiatives in terms of social responsibility

\begin{tabular}{|l|l|}
\hline \multicolumn{1}{|c|}{$\begin{array}{c}\text { Hotel/initiative/ } \\
\text { year of launch/meaning }\end{array}$} & \multicolumn{1}{|c|}{ Objective/pillars } \\
\hline $\begin{array}{l}\text { Accor/ Planet 21/2012 } \\
7 \text { pillars, 21 commitments } \\
\text { made in accordance with the } \\
1992 \text { Rio de Janeiro Earth } \\
\text { Summit Action Plan }\end{array}$ & $\begin{array}{l}\text { Health (healthy interiors, responsible nutrition and } \\
\text { disease prevention); Nature (reduction of water } \\
\text { consumption, recycling, protection of biodiversity); } \\
\text { Carbon Emissions (reduction of energy consumption, } \\
\text { reduction of emissions, stimulation of renewable } \\
\text { energy use); Innovation (in terms of design, } \\
\text { construction and technology); Supporting local } \\
\text { communities (including protecting children from } \\
\text { abuse) } \\
\text { Workforce (including improving the quality of working } \\
\text { conditions); Dialogue (transparency, cooperation, joint } \\
\text { commitments). }\end{array}$ \\
\hline
\end{tabular}




\begin{tabular}{|c|c|}
\hline $\begin{array}{c}\text { Hotel/initiative/ } \\
\text { year of launch/meaning }\end{array}$ & Objective/pillars \\
\hline $\begin{array}{l}\text { Marriott/Spirit to Serve our } \\
\text { Communities/1999 } \\
\text { The initiative has turned into } \\
\text { a stand-alone strategy and } \\
\text { annually the company } \\
\text { publishes a social } \\
\text { responsibility report }\end{array}$ & $\begin{array}{l}\text { Protecting the environment and society; Water, waste } \\
\text { and energy - specific programs to reduce consumption, } \\
\text { re-use of raw materials, recycling of waste; } \\
\text { Encouraging suppliers of green products; Building } \\
\text { hotels based on green standards. }\end{array}$ \\
\hline $\begin{array}{l}\text { Hilton/Travel with Purpose } \\
2030 \text { goals } / 2018 \\
\text { Commitment to reduce } \\
\text { carbon footprint by half and } \\
\text { double the investment with } \\
\text { social impact }\end{array}$ & $\begin{array}{l}\text { Commitment to environment protection (reduction of } \\
\text { carbon emissions, waste, energy and water } \\
\text { consumption, ban plastic straws); Implementation of } \\
\text { the LightStay system to measure and report the } \\
\text { environmental and social impact. }\end{array}$ \\
\hline $\begin{array}{l}\text { InterContinental/ } \\
\text { Responsible Business Report } \\
2018 \\
\text { Sustainable solutions } \\
\text { Green Engage System }\end{array}$ & $\begin{array}{l}\text { Reduce carbon footprint (per occupied room); } \\
\text { Sustainable management of water; Minimize waste and } \\
\text { preserving the environment (for instance, commitment } \\
\text { to remove single use plastic straws, practices on } \\
\text { renovation donation); Use of sustainable products; Use } \\
\text { of local sources for the purchase of goods and services; } \\
\text { Initiatives to determine tourists to make more } \\
\text { environmentally decisions. }\end{array}$ \\
\hline
\end{tabular}

Source: Table elaborated by authors based on Accor Hotels (2012a; 2012b), Marriott (2007), Hilton (2012) and Intercontinental (2018).

InterContinental Hotels Group is ranked by RobecoSAM Consultancy as the number one hotel among active policies in the field of sustainable development (RobecoSAM, 2018).

Beside the four hotels mentioned before, there are also other examples of hotels applying best practices in the field of sustainable bioeconomy in Romania. Vega, a five-star hotel situated in the Mamaia seaside resort, is the first hotel to implement in Romania the EcoHotel Management System and it is annually audited by TÜV Rheinland Romania (a subsidiary of the largest German inspection and certification organization). It has been exclusively using renewable energy since 2013 (Vega Hotel, 2013).

Additionally, two Romanian hotels - Ana Hotels (a four-star hotel situated in Bucharest) and Fimest-Hotel Saturn (a five-star hotel in Mangalia) - hold the EU Ecolabel (European Commission, 2018b).

With several exceptions (Italy with 159 Ecolabelled hotels, France 92, Spain 59, Austria 36 and Switzerland 10), most European countries have only several hotels with this label (European Commission, 2017a). Bărbulescu, Moraru and Duhnea (2019) underscore that "even if managers are aware that EU Ecolabel represents a comparative advantage", the additional costs, difficulty to meet the criteria and also its voluntary character represent real barriers, preventing the widespread presence of such EU Ecolabelled hotels in Romania.

\subsection{The hotel market in Romania}

According to the National Institute of Statistics (INS, 2018), in Romania there were 1,597 hotels in 2017 , of which $96.6 \%$ were with private capital and only $3.4 \%$ state-owned. More 
than $50 \%$ of these are three stars, approximately $20 \%$ of four stars and only $2 \%$ of five stars (Chart no. 1). Most of the hotels are concentrated in Bucharest and other county capital cities (41\%); this implies specific measures for sustainable urban development.

Hotel structure by category of comfort Hotel structure by localization
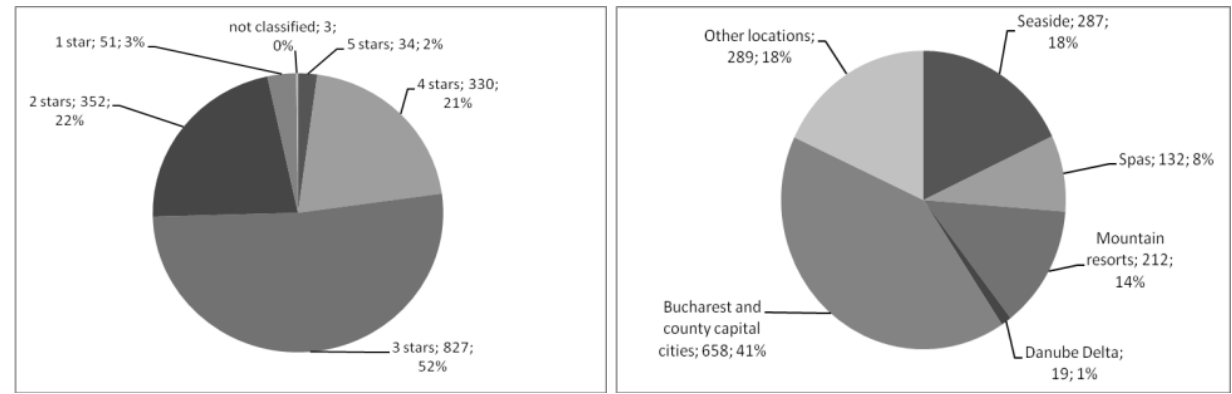

Chart no. 1: Structure of hotels in Romania (category of comfort) and their localization in 2017 (in \%)

Source: Chart elaborated by authors based on INS (2018)

The hotel market in Romania recorded seven consecutive years of growth during 20102017 , with almost 100,000 hotel rooms registering over 20 million overnight stays, a $4 \%$ advance compared to the previous year, respectively 57\% as compared to 2010 (C\&W Echinox, 2018). Utilization rate advanced almost 10 percentage points during 2010-2017, from $29.9 \%$ in 2010 to $39.4 \%$ in 2017 . Accommodation units in Romania received over 12 million tourists in 2017 , of which 2.75 million $(23 \%)$ represent foreign tourists. In terms of hotels, they received 8.56 million tourists ( $71 \%$ of total arrivals), of which 2.37 million $(27.6 \%)$ represent foreign tourists.

The hotel market in Bucharest is dominated by 4-star and 5-star hotels, which represent more than $70 \%$ of the total capacity, while 1 -star and 2 -star hotels account for only $10 \%$. At the same time, almost $47 \%$ of the hotel rooms in Bucharest are operated under the international chain logo, compared to an average of only $7.5 \%$ nationwide. In this hierarchy, the capital city is followed by Sibiu (37.6\%), Oradea $(27.3 \%)$ and Cluj-Napoca (18.9\%) (C\&W Echinox, 2018).

\subsection{Stage of implementing sustainable development criteria in hotels in Romania}

Hotels in the 1-3 star category, with some exceptions (those belonging to international chains, such as the Ibis), lack the human resources and financial capacity required for largescale activities in the field of sustainable development. They use four main ways to support the sustainable bioeconomy: organic products (traditional Romanian cuisine, wood furniture, ecological textiles, and environmentally friendly cleaners), resource saving, waste recycling and renewable energy (solar panels). Approximately half of them do not have their own site, with specific information being accessed on the specific links on the websites of travel operators. About $90 \%$ of one, two and three star hotels have not adopted specific sustainable development measures, and for the remaining 10\%, CSR related information is mainly found in press releases or news, not on companies' websites.

In Romania, most of the hotels are concentrated in the urban environment (INS, 2018). Taking into account that, in the opinion of the European Commission experts, "Cities should become major circular bioeconomy hubs" (European Commission, 2018a), hotels 
can play a significant role in sustainable bioeconomic development. For their part, nonurban hotels can support sustainable development through inputs from nature and the widespread use of renewable energy. Taking into account the specific social responsibility actions of the hotels (Table no. 2), which do not include clear urban development measures, a stronger action of hotels in this area is required.

The 4 and 5-star hotels fall into two categories: those with foreign capital, belonging to international hotel chains and those with majority / integral Romanian capital. Those in the first category have well-defined sustainable development strategies developed by parent companies, while those in the second category do not have such strategies; instead they apply in ad hoc ways the principles of sustainable bioeconomy.

\section{Discussion on interviews results}

Eighteen interviews concerning implementation of sustainable criteria in hotels in Romania completed our scientific work. There were contacted hoteliers from the Federation of Hotel Industry in Romania and the interviews were held with the representatives of the hotels that followed our invitation to participate in this research. The interviews with officials in hotels were conducted during February-March 2019. The questions underlying these interviews were addressed on the basis of the criteria and indicators for hotels set by the Global Sustainable Tourism Council in the document "GSTC Hotel Criteria Version 3, 21 December 2016 with Suggested Performance Indicators".

Due to the limits of an investigation on a representative sample this research is a pilot research that could be a starting point for future research in the field. A summary of the interview results is presented below (Table no. 3). As the research results are ample, we presented a selection of them, emphasizing the respondents' opinion on issues related, mainly, to bioeconomy.

Table no. 3: Synthesis of the research results based on interviews

\begin{tabular}{|l|l|}
\hline \multicolumn{1}{|c|}{ Investigated issues } & \multicolumn{1}{|c|}{ Results } \\
\hline $\begin{array}{l}\text { 1.Sustainable } \\
\text { management system }\end{array}$ & $\begin{array}{l}\text { Only 50\% of participants consider their hotels use a } \\
\text { sustainable management system; 33.3 percent of the } \\
\text { respondents are indecisive in this matter. }\end{array}$ \\
\hline $\begin{array}{l}\text { 2.Legal regulations on } \\
\text { environment }\end{array}$ & $\begin{array}{l}83.3 \% \text { of the participants agree that their hotels have } \\
\text { documents certifying observation of these regulations. }\end{array}$ \\
\hline 3.Sustainable strategies & $\begin{array}{l}\text { Only 33\% of respondents declare they report and } \\
\text { communicate sustainability strategies, results that suggest } \\
\text { hotels should improve these disclosures. }\end{array}$ \\
\hline $\begin{array}{l}\text { 4.Employees' } \\
\text { implement a sustainable } \\
\text { management system }\end{array}$ & $\begin{array}{l}\text { Half of respondents agree that employees are trained / } \\
\text { qualified to implement a sustainable management system; the } \\
\text { other part of the respondents was either indecisive (33.3\%) or } \\
\text { considered that their employees are not trained or qualified } \\
\text { (16.7\%). Again, the results suggest that this matter should be } \\
\text { improved. }\end{array}$ \\
\hline $\begin{array}{l}\text { 5.Customers feedback } \\
\text { on sustainability }\end{array}$ & $\begin{array}{l}\text { All participants agree that the hotels they represent take into } \\
\text { consideration this feedback. Most respondents agreed (66.6\%) } \\
\text { that promotional materials of their hotels are fair and } \\
\text { transparent, including the sustainability issues. }\end{array}$ \\
\hline
\end{tabular}




\begin{tabular}{|c|c|}
\hline Investigated issues & Results \\
\hline $\begin{array}{l}\text { 6.Local and natural } \\
\text { heritage of the area }\end{array}$ & $\begin{array}{l}\text { More than half of the respondents }(67.7 \%) \text { agree that their } \\
\text { employees know and provide information to their clients } \\
\text { about the local and natural heritage of the area. }\end{array}$ \\
\hline $\begin{array}{l}\text { 7.Impact on local } \\
\text { community }\end{array}$ & $\begin{array}{l}\text { All investigated hotels support purchases of goods and } \\
\text { services from local suppliers. The great part of the hotels } \\
\text { support local entrepreneurs who develop products and } \\
\text { services based on local nature, history and culture. All } \\
\text { respondents admit that there are traditional elements of local } \\
\text { culture (design, cuisine, etc.). }\end{array}$ \\
\hline $\begin{array}{l}\text { 8.Purchasing policy on } \\
\text { products that have } \\
\text { environmental } \\
\text { certification }\end{array}$ & $\begin{array}{l}\text { Half of the participants believe hotels favor products and } \\
\text { suppliers that have environmental certification; } 83.4 \% \text { of } \\
\text { respondents agree that hotels make acquisitions to reduce } \\
\text { losses, paying attention to reusable, recycled goods. }\end{array}$ \\
\hline $\begin{array}{l}\text { 9.Energy and water } \\
\text { saving/ Minimizing } \\
\text { greenhouse gas } \\
\text { emissions }\end{array}$ & $\begin{array}{l}\text { More than half of respondents mention their hotels take } \\
\text { actions to reduce energy and water consumption, using also } \\
\text { renewable energy sources. To the question whether there are } \\
\text { procedures in their hotels to avoid or minimize greenhouse } \\
\text { gas emissions, the overwhelming majority of respondents } \\
(83.3 \%) \text { are indecisive. }\end{array}$ \\
\hline $\begin{array}{l}\text { 10.Alternative transport } \\
\text { options }\end{array}$ & $\begin{array}{l}\text { Only } 30 \% \text { of respondents agreed that their hotels encourage } \\
\text { cleaner alternative transport (bicycle rental, car sharing, etc.). }\end{array}$ \\
\hline $\begin{array}{l}\text { 11.Minimizing the use } \\
\text { of harmful substances }\end{array}$ & $\begin{array}{l}66.7 \% \text { of the participants mention that hotels take measures to } \\
\text { minimize the use of harmful substances (ex.: disinfectants or } \\
\text { cleaning materials) and their replacement with } \\
\text { environmentally friendly alternatives. }\end{array}$ \\
\hline $\begin{array}{l}\text { 12.Policies on the } \\
\text { reduction, reuse and } \\
\text { recycling of solid waste }\end{array}$ & $\begin{array}{l}66.7 \% \text { of respondents agree their hotels have such policies. } \\
\text { Almost } 60 \% \text { of respondents admit that their hotels treat } \\
\text { wastewater and reuse or evacuate them only in safe conditions } \\
\text { for people and environment. }\end{array}$ \\
\hline
\end{tabular}

The great part of the respondents $(66.7 \%)$ mentions their hotels do not have a social responsibility code. Publication of the results of the hotels involvement in CSR activities is on voluntary basis for overwhelming part of the participants $(83.3 \%)$. All interviewees consider that the hotels they operate in comply with the principles of business ethics.

\section{Conclusions}

Bioeconomy contributes, to a great extent, to the achievement of the UN Sustainable Development Goals. Sustainable hospitality industry has close links with bioeconomy, applying and promoting its practices such as: reducing pollution, minimizing energy and water consumption, using renewable resources, reducing solid waste, and using local natural products in their restaurants. Therefore, CSR could play an important role in achieving the objectives of sustainable development and bioeconomy. Hotels that are responsible have various initiatives to protect environment, use renewable resources, promote natural resource purchases, increase tourists' awareness on environmental issues, etc. 
This paper has analyzed the literature from the perspective of strong links between CSR, bioeconomy and hotel industry, concluding that there is no such investigation in Romania until the present study. In this context, we have examined the bioeconomy strategies and practices implemented by the Romanian hotels and we have analyzed the stage of the application of sustainable development criteria. The present study might generate theoretical and practical implications in the hospitality industry in Romania, providing managers with support for future directions of action in implementing strategies specific to bioeconomics.

On the Romanian market there is a clear distinction between four and five star hotels and other categories as regards CSR in the hotel industry. Hotels in the first category, with larger financial resources and often belonging to international chains, are more active in this area, benefiting from the strategies within the group. In contrast, hotels in the second group do not have the resources needed for large-scale activities in the field of social responsibility, so they can resort to a limited number of ways to develop the bioeconomy. CSR in Romania could be a key-factor in determining all types of companies, including those in the hotel industry to support global initiatives towards responsible business behavior, sustainable development, and bioeconomy. However, as long as CSR does not become mandatory, its voluntary nature will remain a barrier that prevents more intense actions. Therefore, we propose introducing legislative measures to stimulate all companies, irrespective of their size, to report nonfinancial information as well as the implementation of measures to raise the level of awareness and action of the employees, tourists and all the stakeholders involved in respecting and promoting the bioeconomy. A limitation of this research is related to the reluctance and lack of information on bioeconomy and the application of sustainable criteria in hotels in Romania. Current research is only a first step in the analysis of the subject, which in the future can be developed by expanding research into large-scale, financially supported projects that will allow the investigation of a larger number of subjects.

\section{References}

Abaeian, V., Yeoh, K.K. and Khong, K.W., 2014. An exploration of CSR initiatives undertaken by Malaysian hotels: Underlying motivations from a managerial perspective. Procedia - Social and Behavioral Sciences, 144, pp. 423-432.

Accor Hotels, 2012a. Planet 21 program. [pdf] Available at: <https://www.sofitel-dubaithepalm.com/wp-content/uploads/sites/15/2016/08/Planet-21-program.pdf $>$ [Accessed 24 February 2019].

Accor Hotels, 2012b. Planet 21 program. [pdf] Available at: <https://www.greenbiz.com/ news/2012/04/17/accors-planet-21-program-brings-sustainability-all-its-hotels> [Accessed 24 March, 2019].

Accountability Framework, 2018. The Accountability Framework Core Principles for Setting, implementing, and monitoring effective commitments on deforestation, ecosystem conversion, and human rights in responsible supply chains. Revised draft for workshopping. [pdf] Available at: <https://accountability-framework.org/wp-content/ uploads/2018/12/Accountability-Framework-Core-Principles-DRAFT-2018-12.pdf> [Accessed 19 March 2019].

Anand, M., 2016. Innovation and Sustainable Development: A Bioeconomic Perspective. Brief for GSDR - 2016 Update. [pdf] Available at: <https://sustainabledevelopment. 
un.org/content/documents/982044_Anand_Innovation\%20and\%20Sustainable\%20Deve lopment_A\%20Bioeconomic\%20Perspective.pdf> [Accessed 16 March 2019].

Băleanu, T.E., Chelcea, L. and Stancu, A., 2011. The Social Responsibility of the Top 100 Romanian Companies. An Analysis of Corporate Websites. Amfiteatru Economic, 13(29), pp.235-248.

Bărbulescu, A., Moraru, A.D. and Duhnea, C., 2019. Ecolabelling in the Romanian Seaside Hotel Industry-Marketing Considerations, Financial Constraints, Perspectives. Sustainability, 11(1), p.265.

Biobased Industries Consortium, 2018. Bioeconomy and the UN Sustainable Development Goals. A view from the Bio-based Industries Consortium. [pdf] Available at: <https://biconsortium.eu/sites/biconsortium.eu/files/documents/Bioeconomy_and_the_S DGs_July\%202018.pdf> [Accessed 16 March 2019].

Blešić, I., Čerović, S. and Dragićević, V., 2011. Improving the service quality as a socially responsible activity of hotel companies. Amfiteatru Economic, 13(29), pp. 273-286.

Carroll, A.B., 2008. A History of Corporate Social Responsibility: Concepts and Practices. In: Crane, A., McWilliams, A., Matten, D., Moon, J. and Siegel D. (eds.). The Oxford Handbook of Corporate Social Responsibility. Oxford University Press, pp. 19-46.

Cohen, E., 1978. The Impact of Tourism on the Physical Environment. Annals of Tourism Research, 5(2), pp. 215-237.

C\&W Echinox, 2018. Romania Hotel Market 2017. [pdf] Available at: <https://cwechinox.com/wp-content/uploads/2018/03/Hotel-MarketRomania_2017.pdf> [Accessed 23 March 2019].

European Bioeconomy Alliance (EBA), 2018. The crucial role of the bioeconomy in achieving the UN Sustainable Development Goals. [pdf] Available at: <https://bioeconomyalliance.eu/sites/default/files/EUBA\%20SDGs\%20final.pdf> [Accessed March 16 2019].

European Commission, 2017a. The EU Ecolabel Tourist Accomodation Catalogue. [online] Available at: <http://ec.europa.eu/ecat/hotels/en/list> [Accessed 10 March 2019].

European Commission, 2018a. A Sustainable Bioeconomy for Europe: Strengthening the connection between economy, society and the environment. Updated Bioeconomy Strategy, Directorate-general for Research and Innovation, Brussels, October. [pdf] Available at: <https://ec.europa.eu/research/bioeconomy/pdf/ec_bioeconomy_strategy_ 2018.pdf\#view=fit\&pagemode=none $>$ [Accessed 16 March 2019].

European Commission, 2018b. EU Ecolabel, Facts and Figures. [online] Available at: <http://ec.europa.eu/environment/ecolabel/facts-and-figures.html> [Accessed $27 \mathrm{March}$ 2019].

Eurostat, 2019. Nights spent at tourist accommodation establishments - monthly data. [online] Available at: <http://appsso.eurostat.ec.europa.eu/nui/setupDownloads.do> [Accessed 20 June 2019].

Forbes, 2018. The World Largest Public Companies. [online] Available at: <https://www.forbes.com/global2000/list/\#industry:Hotels\%20\%26\%20Motels> [Accessed 26 March 2019]. 
Global Reporting Initiative (GRI), 2013. Sustainability Topics for Sectors. Research and Development Series. [pdf] Available at: <https://www.globalreporting.org/ resourcelibrary/sustainability-topics.pdf> [Accessed 26 March 2019].

GRI, 2019. Sustainability Disclosure Database. [online] Available at: <https://www.globalreporting.org/Pages/default.aspx> [Accessed 21 March 2019].

Global Sustainable Tourism Council (GSTC), 2016. GSTC Hotel Criteria, Suggested Performance Indicators. [online] Available at: <https://www.gstcouncil.org/gstccriteria/gstc-industry-criteria-for-hotels/> [Accessed 20 December 2018].

Government of Romania, 2018. The National Strategy for Romania's Sustainable Development 2030. [pdf] Available at: <https://www.edu.ro/sites/default/files/Strategianationala-pentru-dezvoltarea-durabila-a-Rom\%C3\%A2niei-2030.pdf $\quad$ [Accessed 26 March 2019].

Grigoras, L.M. and Albu, R.G., 2015. Study on the involvement of tourism companies into CSR actions. [pdf] Available at: <http://webbut.unitbv.ro/BU2015/Series\%20V/ BILETIN\%20I/23_Albu\%20R.pdf> [Accessed 27 March 2019].

Hilton Hotels, 2012. Our Reporting Performance. [online] Available at: <https://cr.hilton.com/our-reporting/> [Accessed 24 February 2019].

Intercontinental Hotels Group (IHG), 2018. Our 2018 Performance. [online] Available at: <https://www.ihgplc.com/en/responsible-business/targets-and-reporting> [Accessed 24 March 2019].

Ionescu, G.H., Firoiu, D., Pîrvu, R., Bădîrcea, R. and Drăgan, C., 2018. Implementation of Integrated Management Systems and Corporate Social Responsibility Initiatives-A Romanian Hospitality Industry Perspective. Sustainability, 10(10), p.3684.

International Organization for Standardization (ISO), 2010. ISO 26000:2010. [online] Available at: 〈https://www.iso.org/obp/ui/\#iso:std:iso:26000:ed-1:v1:en> [Accessed 20 March 2019].

Jashi, C., 2018. Application of Social Marketing for Sustainable Tourism Development. International Scientific Journal, 1(1), pp.19-28.

KPMG, 2018. Measuring Progress in Sustainability Using the Best Tools Available Support for Participating in the DJSI Evaluation, [pdf] Helsinki. Available at: <https://assets.kpmg/content/dam/kpmg/fi/pdf/2018/02/KPMG_DJSI\%20process\%20se rvices_2018.pdf $>$ [Accessed 6 March 2019].

Mak, A.H.N. and Chang, R.C.Y., 2019. The driving and restraining forces for environmental strategy adoption in the hotel Industry: A force field analysis approach. Tourism Management, 73, pp.48-60.

Mandl, I. and Dorr, A., 2007. CSR and Competitiveness European SMEs' Good Practice. Consolidated European Report. [online] Vienna: Austrian Institute for SME Research. Available at: <https://www.eldis.org/document/A40382> [Accessed 16 February 2019].

Marriott Hotels, 2007. Social Responsability Report. [pdf] Available at: <https://www. marriott.com/hotelwebsites/us/c/caieg/caieg_pdf/Spirit\%20to\%20serve\%20our\%20com munities\%20-\%20social\%20responsibility.pdf> [Accessed 16 February 2019].

Moisescu, O.I., 2014. A Website-Based Analysis Regarding CSR Practices of the Top Romanian Travel Agencies. [pdf] MPRA Paper No. 65288. Available at: <https://mpra. ub.uni-muenchen.de/65288/1/MPRA_paper_65288.pdf> [Accessed 27 March 2019]. 
Murphy, P.E., 1978. An Evolution: Corporate Social Responsiveness. University of Michigan Business Review, 30(6), pp.19-25.

National Institute for Research on Chemistry and Petrochemistry (ICECHIM), 2016. Research on the identification of priorities for the development of bio-economy in Romania for the period 2016-2030, Research Project. [online] Available at: <http://www.incdsb.ro/p/Sectorial-Bioeconomie/index.html> [Accessed 20 June 2019].

National Institute of Statistics (INS), 2018. Romanian Tourism Statistical Abstract. [pdf] Available at: <http://www.insse.ro/cms/sites/default/files/field/publicatii/turismul_ romaniei_2018_breviar_statistic.pdf> [Accessed 23 March 2019].

Obrad, C., Petcu, D., Gherheş, V. and Suciu, S., 2011. Corporate Social Responsibility in Romanian Companies - between Perceptions and Reality. Amfiteatru Economic, 13(29), pp.43-55.

Organisation for Economic Co-operation and Development (OECD), 2018. Romania. In: OECD Tourism Trends and Policies 2018. Paris: OECD Publishing, pp.360-364.

Przezbórska-Skobiej, L., 2017. Tourism in the bioeconomy of Poland (regional perspective). Turystyka i Rozwój Regionalny. Journal of Tourism and Regional Development, 7, pp.71-80.

Ricaurte, E., 2018. Benchmarking index 2018: Carbon, energy, and water. Ithaca, New York: Cornell University School of Hotel Administration, Center for Hospitality Research.

RobecoSAM, 2018. Dow Jones Sustainability Index, Review Results, September. [pdf] Available at: <https://www.robecosam.com/media/0/4/3/043cd016c8d1952fdd23ee4b2 dac909d_review-presentation-2018_tcm1016-14658.pdf> [Accessed 23 March 2019].

Sindhi, S., Padhi, M. and Maurya, U.K., 2018. Corporate Social Responsibility and Corporate Image Resurrection: Cases of Mining Firms in Odisha. In: Adhikari, A., Strategic Marketing Issues in Emerging Markets. Singapore: Springer, pp. 343-361.

United Nations (UN), United Nations World Tourism Organization (UNWTO), 1999. Global Code of Ethics for Tourism, adopted by resolution A/RES/406(XIII) at the thirteenth WTO General Assembly, Santiago, Chile, 27 September - 1 October 1999.

UN, 2000. United Nations Millennium Declaration, New York.

United Nations Global Compact (UNGC), 2014. Guide to Corporate Sustainability, December. [pdf] Available at: <https://www.unglobalcompact.org/docs/ publications/ UN_Global_Compact_Guide_to_Corporate_Sustainability.pdf> [Accessed 27 March 2019].

UN, 2015. Transforming our world: the 2030 Agenda for Sustainable Development. [online] Available at: <https://www.un.org/sustainabledevelopment/developmentagenda/> [Accessed 27 March 2019].

Vega Hotel, 2013. Vega became the first hotel in Romania to use Green Energy. [online] Available at: <https://www.hotelvega.ro/en/news-and-events/first-hotel-romaniaconsumer-renewable-green-energy.html> [Accessed 27 March 2019]. 